\title{
o1. Çocuk yazınında karakter geliştirme bağlamında Aytül Akal'ın masal kitapları
}

\section{Bora BAYRAM1}

\begin{abstract}
APA: Bayram, B. (2021). Çocuk yazınında karakter geliştirme bağlamında Aytül Akal'ın masal kitapları. RumeliDE Dil ve Edebiyat Araştırmaları Dergisi, (23), 1-14. DOI: 10.29000/rumelide.948283.
\end{abstract}

Öz

Çocuğun her şeyiyle kendine has dünyasında çocuk kitaplarının yeri ayrıdır. Çünkü çocuklar, çocuk edebiyatı ürünleri vasıtasıyla farklı farklı pek çok karakterle tanışmaktadırlar. Bu karakterler, sahip oldukları olumlu nitelikler dolayısıyla çocuk için rol model teşkil etmektedir. Bundan dolayı çocuk edebiyatı yazarları, sözcü olarak belirledikleri kitap kahramanları yardımıyla çocuğun dünyasına dâhil olarak onlara iyiyi, güzeli ve doğru olanı seçme konusunda ipuçları sunmaktadır. Bu bağlamda kurgulanan eserlerdeki karakterlerin nasıl geliştirildiği önem taşımaktadır. Çünkü çocuk edebiyatı ürünlerinde rol model olmada aracı kılınan karakterlerin konuşmaları, davranışları, görünüşleri, diğer karakterler veya yazar tarafından algılanışlarıyla ilgili detaylar yardımıyla çocuklara doğrudan veya dolaylı şekilde pek çok mesajlar verilmektedir. $\mathrm{Bu}$ araştırmada çocuk yazınında karakter geliştirme açısından Aytül Akal'ın çocuk kitaplarının incelenmesi amaçlanmıştır. Bunun için Akal'ın çocuk kitaplarındaki karakterler tespit edilerek karakter çeşitleri ve karakter geliştirme bakımından taşıdığı özelliklere bakılmıştır. Tarama modelinde betimsel nitelikteki bu çalışmada Akal'ın üç farklı masal serisinde yer alan toplam 24 adet kitap içerik analiziyle incelenmiştir. Araştırma verilerini desteklemesi bakımından betimsel analiz yöntemi de araştırmada kullanılmıştır. Araştırma sonucunda elde edilen veriler, yüzde ve sıklık (frekans) olarak ifade edilerek tablolaştırılmıştır. Araştırma sonucunda Akal'ın incelenen masal türü eserlerinin tamamında kapalı ve durağan karakterlerin daha çok kullanıldığı, Lukens’in karakter geliştirme yollarının tamamına rastlandığı, tüm masal serilerinde karakterlerin en çok davranışlarla geliştirildiği tespit edilmiştir.

Anahtar kelimeler: Çocuk edebiyatı, karakter geliştirme, Aytül Akal

\section{Aytül Akal's fairy tale books in the context of character development in children's literature}

\begin{abstract}
Children's books have a special place in the child's unique world. Because children meet many different characters through children's literature works. These characters serve as role models for the child due to their positive qualities. Therefore, writers of children's literature take part in the world of the child through the book and offer them tips on choosing the good, beautiful and right with the help of the book heroes they have determined as spokespersons. In this context, it is important how the characters in the fictionalized works are developed. Because many messages are conveyed to children directly or indirectly with the help of details about the speech, behavior, appearance, perception of the characters by other characters or the author, who are the role models in children's literature. In this research, it is set out to examine Aytül Akal's children's books in
\end{abstract}

Dr. Öğr. Üyesi, Alanya Alaaddin Keykubat Üniversitesi, Eğitim Fakültesi, Türkçe ve Sosyal Bilimler Eğitimi Bölümü, Türkçe Eğitimi ABD (Alanya, Antalya, Türkiye), bora.bayram@alanya.edu.tr, ORCID ID: 0000000206934651 [Araştırma makalesi, Makale kayıt tarihi: 02.02.2021-kabul tarihi: 20.06.2021; DOI: 10.2900o/rumelide.948283]

Adres | Address

RumeliDE Dil ve Edebiyat Araştırmaları Dergisi $\quad$ RumeliDE Journal of Language and Literature Studies Osmanağa Mahallesi, Mürver Çiçeği Sokak, No:14/8 $\quad$ Osmanağa Mahallesi, Mürver Çiçeği Sokak, No:14/8

Kadıköy - İSTANBUL / TÜRKIYE 34714 Kadıköy - ISTANBUL / TURKEY 34714 e-posta: editor@rumelide.com

e-mail: editor@rumelide.com,

tel: +90 505 7958124, +90 216773 o 616 phone: +90 505 7958124, +90 2167730616 
terms of character development in children's literature. For this, firstly, the characters in Akal's children's books have been determined and the character types have been tried to be determined, and then their features in terms of character development have been examined. In this descriptive study conducted in descriptive survey model, a total of 24 books in Akal's three different fairy tale series have been analyzed through content analysis. Descriptive analysis method has also been used in the research to support the research data. The data obtained as a result of the research have been presented in tables by expressing the percentage and frequency. As a result of the research, it has been determined that closed and stable characters are used more in all of Akal's fairy tale works, all of Lukens's methods of character development is used in the works, and characters are mostly developed with behaviors in all fairy tale series.

Keywords: Children's literature, character development, Aytül Akal

\section{Giriş}

Çocukluk dönemindeki kimselerin duygu, düşünce ve hayallerine dair yazılı ve sözlü tüm eserleri içeren (Oğuzkan, 2000: 3) çocuk edebiyatı; ele aldığı konular, kurgusu ve dili bakımından çocukların ruh dünyasına hitap etmektedir. Nitekim çocuklar için meydana getirilmiş bir edebiyat olan çocuk edebiyatı, çocukların dil gelişimlerine katkı sunarak onların edebiyat ihtiyacını karşılamaktadır (Dursunoğlu, 2013: 31). Çocukların düşünerek, duyarak karar verebilme yeterliliğine sahip duyarlı birer birey olarak yetiştirilmesine dönük bir çabanın sonucu olan (Seven, 2010: 24) çocuk edebiyatı, sunduğu yaşam deneyimiyle çocuklara içinde yaşadıkları toplumdaki insan ilişkileriyle farklı kültürlerdeki insan ilişkilerini tanıma ve karşılaştırma olanağı sunar. Toplum içinde kabul gören veya görmeyen, beğenilen veya karşı çıkılan tutum ve davranışların sezilmesi; anne, baba, kardeş dışındaki sosyal çevrenin tanınması ve bunlar arasındaki farklı iletişim biçimleri vasıtasıyla sorunların çözümü, sevinç, paylaşma, dayanışma duygularının örneklendiği farklı yaşantılar sunması bakımından çocuk kitaplarının yeri yadsınamaz (Karagül, 2019: 48-49). Çocuk kitapları içinde hem yetişkin hem de çocuklar açısından zenginleştirici ve tatmin edici bir tür olarak masallar öne çıkmaktadır. İnsanların içsel problemlerinin ve toplumda yaşanılan zor durumların doğru kanallarla çözümü bakımından herhangi bir hikâye çeşidine nispeten masallar daha öğreticidir. Masallar sayesinde çocuk, içsel kaynaklarının müsaade ettiği ölçüde içinde yaşadığı toplumun koşullarıyla da başa çımayı öğrenecektir (Bettelheim, 2019: 9-10).

Nitelikli çocuk edebiyat yapıtları; çocuğun bilişsel, dilsel, toplumsal, ruhsal, kişilik gelişimini ve çocuk gerçekliğini göz ardı etmemesinin yanında edebî niteliğinden de taviz vermeksizin hazırlanmıştır (Dilidüzgün, 2005: 41). Bununla birlikte çocuk edebiyatı ürünlerinin çocuğa görelik ilkesi doğrultusunda hazırlanmış olması da beklenmektedir. Çocuğa görelik; çocuğun seviyesine inip ona onun anlayacağı bir dille seslenmek, onun ilgi ve ihtiyaçlarına göre yapıtı tasarlamak demektir. Bunun gerçek olabilmesi de ancak çocuğu tanımak, onun nelerden hoşlandığını bilerek eser hazırlamakla mümkündür (Şirin, 1998: 4). Nitekim çocuklar; şarkıları, dansları, resimleri, kıyafetleri, oyunları vs. ile yetişkin insanlardan farklıdır (Önder, 2019: 6)

Çocuk kitaplarında yazarlar asıl söylemek istediklerini kendilerine sözcü olarak seçtikleri karakterler üzerinden vermektedirler. Bu durum bir zaman çocuk kitaplarında kusursuz, hatasız, melek kadar iyi karakterlerin ortaya çıkmasına sebep olsa da son dönemde bunun yerine daha insani karakterlerin oluşturulması söz konusudur (Karataş, 2014: 65-66). Çocuk kitaplarındaki karakterlerin günlük yaşamda karşllı̆̆ı olan, gerçeğe uygun olaylara karşı tutumları çocuk okurların söz konusu kahramana

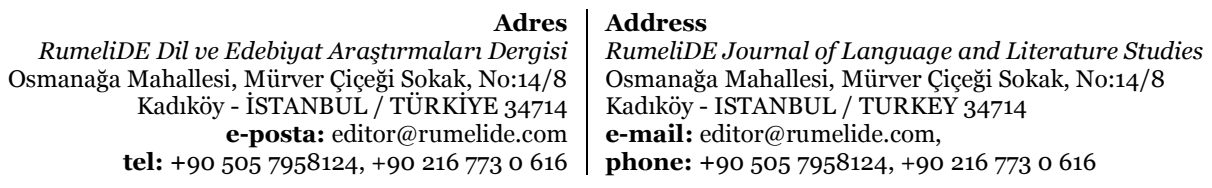


sempati duymasını ve onu gizil model almasını tetiklemektedir (Kıymaz, 2019: 634). Bu bağlamda karakterlerin tek boyutlu değil, çok yönlü aktarılması gerekmektedir (Burç, 2013: 7). Şimşek’e (2011) göre çocuk kitaplarındaki karakterler; evrensel ve ahlaki değerlere sahip, iyiliğin ve doğruluğun savunusu, barışı destekleyici, çevresini ve kültürel değerlerini koruyan, adil, çalışkan ve yardımsever olma gibi niteliklere sahip olursa çocuk o karakterle kendini özdeşleştirebilir. Ancak çocukların okudukları öykülerde kendi kopyalarını görmelerine de gerek yoktur. Çünkü kurmaca yazın, farklı yaşantılara tanık olmaya ve istenilen kişi veya karakterlerle bütünleşmeye imkân tanır (Rundell, 2020: $58)$.

Çocuklar, okudukları her yeni kitapla birlikte yeni karakterlerle tanışarak yeni yaşantılara tanık olur, ve farklı tecrübeler elde ederler (Şimşek, 2011: 104) Bu yüzden çocuğun özdeşim kurduğu karakterlerin çocuğa örnek olabilecek niteliklere sahip olması gerektiği bir gerçektir (Ceran, 2015: 138). Bununla birlikte çocuğa yönelik eserlerde yer alan karakterlerin haddinden fazla olması da çocuğun hedef davranışa dönük odağını değiştirebileceğinden sakıncalı olabilir.

Çocuk kitaplarında yer alan karakterler, rastgele bir kurguyla değil, yaş ve seviye gözetilerek çocuğun ana kahramanla özdeşim kurmasına açık olan hedef davranışını öne çıkarmak üzere iyi düşünülerek tasarlanmalıdır. Bu tasarlama sürecinde insan karakterler kadar hayvan karakterler de oldukça sık kullanılır. Hayvan karakterler çocuk kitaplarında hayvansı özelliklerini yitirerek insansı nitelikleriyle karşımıza çıkmaktadır. Bu bağlamda yetişkinlerin dünyasında bilgi, cüsse, akıl gibi nitelikler karşısında ezilen çocuğun hayvanlarla özdeşim kurması daha anlaşılırdır. Bununla birlikte çocuk okurun muhtemel kötü davranışlar sergileyen kahramana karşı özdeşim kurmaktan çok savunma refleksi geliştirmesi söz konusudur. Bundan dolayı, kahraman olarak eğer hayvan karakterler seçilmişse, çocuk okur olumsuz davranışı yabancılaştırma etkisiyle kendinden uzaklaştırır ancak kitapta verilen mesaja duygusal bir blokaj koyması da önlenmiş olur (Erdoğan, 2019: 89).

Çocuk yazınında yazarın geliştirdiği karakterler, sahip oldukları niteliklere göre farklı şekillerde sınıflandırılabilir. Sever’in (2015) karakter özellikleriyle ilgili sınıflamasına göre karakterler açık ve kapalı karakter olmak üzere iki grupta incelenebilir. Buna göre açık karakterler okurun iyi bildiği, inandırıcılık özellikleriyle önce çıkan ve yazarın vermek istediği mesajın paylaşılmasında sorumluluk üstlenen karakterdir. Kapalı karakterlerse kahramanın kişilik özelliklerinin onaylanmasına ve anlaşılmasına yardımcı olan, esas kahramanın yönlendirdiği olayın sonucundan etkilenen karakterdir (Sever, 2015: 104-105). Yardımcı karakterler, kahramanın bazı eksikliklerinin kapatılmasına, çözüm arayışlarına, kimi seçeneklerin elenmeden önce okurla paylaşılmasına yardımcı olurlar (Erdoğan, 2019: 115)

Karakter özelliklerini durağan ve kapalı olarak sınıflandıran Lukens'e (2007) göre anlatı süresince değişen, dönüşen karakterler devingen; herhangi bir değişikliğe uğramayan karakterlerse durağan karakter olarak sınıflandırılmıştır.

Bunlar dışında olaya dayalı metinlerdeki karakterlere ilişkin bir diğer sınıflamaysa Lukens'in (2007) karakter geliştirme yollarına dair yapmış olduğu beş alt başlıktan meydana gelen tasniftir. Buna göre karakterler davranış ve eylemler, konuşmalar, fiziki özellikler, diğer karakterlerin yorumu ve anlatıcın yorumu vasıtasıyla geliştirilmektedir. Buna göre çocukların, eser kahramanlarını rol model olarak görebildikleri ve onlara ne denli yakın oldukları düşünüldüğünde bu karakterlerin davranışlarıyla mı, konuşmalarıyla $\mathrm{ml}$, fiziksel özellikleriyle $\mathrm{mi}$, diğer karakterlerin yorumuyla $\mathrm{mı}$ yoksa yazarın yorumuyla mı şekillendiği sorusu da akla gelmektedir. Çünkü rol model olmada aracı kılınan unsur

\footnotetext{
\begin{tabular}{r|l} 
Adres & Address \\
RumeliDE Dil ve Edebiyat Araşttrmalar Dergisi & RumeliDE Journal of Language and Literature Studies
\end{tabular} Osmanağa Mahallesi, Mürver Çiçeği Sokak, No:14/8 Osmanağa Mahallesi, Mürver Çiçeği Sokak, No:14/8 Kadıköy - İSTANBUL / TÜRKIYE 34714 Kadıköy - ISTANBUL / TURKEY 34714 e-posta: editor@rumelide.com e-mail: editor@rumelide.com, tel: +90 505 7958124, +90 2167730616 phone: +90 505 7958124, +90 2167730616
} 
vasıtasıyla çocuğa üstü kapalı olarak güzel konuşmak, güzel davranmak, iyi bahsedilmek, iyi görünmek, iyi algılanmak gibi mesajlar da verilmektedir.

$\mathrm{Bu}$ araştırmada çocuk yazınında karakter geliştirme açısından Aytül Akal'ın çocuk kitaplarının incelenmesi amaçlanmıştır. Bunun için öncelikle Akal’ın çocuk kitaplarındaki karakterler tespit edilerek karakter çeşitleri belirlenmeye çalışılmıştır. Ardından da bu karakterlerin karakter geliştirme bakımından taşıdığı özelliklere bakılmıştır. Bu doğrultuda aşă̆ıdaki araştırma sorularına cevap aranmıştır:

1. Aytül Akal'ın çocuk kitaplarında yer alan karakterin karakter çeşitleri sınıflamasına göre dağılımı nasıldır?

2. Aytül Akal'ın çocuk kitaplarında yer alan karakterlerin karakter geliştirme sınıflamasına göre dağılımı nasıldır?

\section{Yöntem}

\section{Araşturmanın modeli}

Aytül Akal'ın masal kitaplarında yer alan karakterlerin, karakter geliştirme yolları bakımından incelendiği bu çalışma, tarama modelinde betimsel bir çalışmadır. Bu tür araştırmalarda var olan bir durum, var olduğu şekliyle ortaya konmaya çalışılmaktadır (Karasar, 2009). Aytül Akal'ın masal kitabı serilerinden üçü örneklem olarak belirlenerek söz konusu kitaplarda yer alan masallar, karakter geliştirme yollarına göre incelenmiştir. İncelemede betimsel çözümleme çeşitlerinden kategorisel çözümleme yöntemi kullanılmıştır.

\section{Çalsşma materyalleri}

Araştırmanın çalışma materyalini Aytül Akal'ın yazmış olduğu Güzel Dünyamıza Masallar, Çocuğuma Masallar, Orman Masalları isimli masal serilerinde yer alan toplam 24 masal kitabı oluşturmaktadır. Bu kitaplara ilişkin bilgiler Tablo 1'de verilmiştir.

Tablo 1. Araştırmanın inceleme nesnesi olarak belirlenen masal kitaplari

\begin{tabular}{|c|c|c|c|c|c|c|c|}
\hline Sira & Seri & Eserin İsmi & \multicolumn{2}{|c|}{ Yayınevi } & Sayfa & $\begin{array}{l}\text { Yayım } \\
\text { Yilı }\end{array}$ & Baskı \\
\hline 1 & & Canı Sıkılan Aydede & \multicolumn{2}{|c|}{ Uçanbalık Yayınları } & 16 & 2017 & 10. baskı \\
\hline 2 & & Cadı Burunlu Fabrika & \multicolumn{2}{|c|}{ Uçanbalık Yayınları } & 16 & 2017 & 4. baskı \\
\hline 3 & & Park Yiyen Robot & \multicolumn{2}{|c|}{ Uçanbalık Yayınları } & 16 & 2016 & 5. baskı \\
\hline 4 & పี & $\begin{array}{l}\text { Denizin Altını Merak Eden } \\
\text { Vapur }\end{array}$ & \multicolumn{2}{|c|}{ Uçanbalık Yayınları } & 16 & 2017 & 7. baskı \\
\hline 5 & ఫ్రి & Buruşuk Kâğıt Parçası & \multicolumn{2}{|c|}{ Uçanbalık Yayınları } & 16 & 2016 & 6. baskı \\
\hline 6 & 芯 & Rengini Arayan Top & \multicolumn{2}{|c|}{ Uçanbalık Yayınları } & 16 & 2017 & 5. baskı \\
\hline 7 & हี & Yaramaz Trafik Lambası & \multicolumn{2}{|c|}{ Uçanbalık Yayınları } & 16 & 2016 & 8. baskı \\
\hline 8 & : & Işığını Yitiren Yıldız & \multicolumn{2}{|c|}{ Uçanbalık Yayınları } & 16 & 2015 & 5. baskı \\
\hline 9 & : & Bu Dünya Kimin & \multicolumn{2}{|c|}{ Uçanbalık Yayınları } & 16 & 2016 & 6. baskı \\
\hline & & $\begin{array}{r}\text { RumeliDE Dil ve Edebiyat Arassttrm } \\
\text { Osmanağa Mahallesi, Mürver Ciçeği S } \\
\text { Kadıköy - İSTANBUL / Tü } \\
\text { e-posta: editor@ } \\
\text { tel: }+90 \text { 505 7958124, +90 }\end{array}$ & $\begin{array}{l}\text { Adres } \\
\text { Dergisi } \\
\text { No:14/8 } \\
\text { E } 34714 \\
\text { lide.com } \\
73 \text { o } 616\end{array}$ & \multicolumn{4}{|c|}{$\begin{array}{l}\text { Address } \\
\text { RumeliDE Journal of Language and Literature Studies } \\
\text { Osmanağa Mahallesi, Mürver Çiçeği Sokak, No:14/8 } \\
\text { Kadıöy - ISTANBUL / TURKEY } 34714 \\
\text { e-mail: editor@rumelide.com, } \\
\text { phone: +90 505 7958124, +90 } 216773 \text { o } 616\end{array}$} \\
\hline
\end{tabular}




\begin{tabular}{|c|c|c|c|c|c|c|}
\hline 10 & \multirow{9}{*}{ 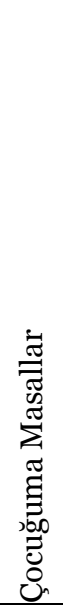 } & Ben Büyüğüm & Uçanbalık Yayınları & 16 & 2017 & 7. baskı \\
\hline 11 & & Dağınık Çocuk & Uçanbalık Yayınları & 16 & 2016 & 10. baskı \\
\hline 12 & & Küçük Anne & Uçanbalık Yayınları & 16 & 2017 & 5. baskı \\
\hline 13 & & Nerden Çıktı Bu Kardeş & Uçanbalık Yayınları & 16 & 2017 & 7. baskı \\
\hline 14 & & Yaşlı Çocuk & Uçanbalık Yayınları & 16 & 2010 & 3. baskı \\
\hline 15 & & Terlikleri Kim Giyecek & Uçanbalık Yayınları & 16 & 2017 & 6. baskı \\
\hline 16 & & Bütün Oyuncaklar Benim & Uçanbalık Yayınları & 16 & 2016 & 8. baskı \\
\hline 17 & & Ben Ne Zaman Büyüyeceğim & Uçanbalık Yayınları & 16 & 2016 & 7. baskı \\
\hline 18 & & Ben Ne Olacağım & Uçanbalık Yayınları & 16 & 2015 & 6. baskı \\
\hline 19 & \multirow{6}{*}{ 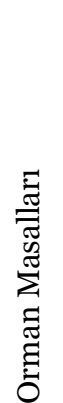 } & Suda Oynamayı Kim Sevmez & Uçanbalık Yayınları & 16 & 2015 & 5. baskı \\
\hline 20 & & Küçük Kertenkele & Uçanbalık Yayınları & 16 & 2011 & 3. baskı \\
\hline 21 & & Ormandaki Apartman & Uçanbalık Yayınları & 16 & 2016 & 4. baskı \\
\hline 22 & & Masalını Arayan Ejderha & Uçanbalık Yayınları & 16 & 2016 & 5. baskı \\
\hline 23 & & Ormanın Renkleri Kimde & Uçanbalık Yayınları & 16 & 2013 & 5. baskı \\
\hline 24 & & Ormanın Yeni Komşuları & Uçanbalık Yayınları & 16 & 2017 & 5. baskı \\
\hline
\end{tabular}

\section{Verilerin toplanması ve çözümlenmesi}

İncelenen eserlerdeki karakterlere yönelik elde edilen veriler, farklı karakter sınıflamaları dikkate alınarak kategorize edilmiştir. Araştırılacak olan eserlerdeki karakter özelliklerini tespit etmek üzere Sever'in (2015), kapalı ve açık karakterler ile Lukens'in (2007) durağan ve devingen karakterler şeklindeki sınıflamalarından istifade edilmiştir. Karakter geliştirme yollarını tespit etmek içinse Lukens (2007) tarafından ortaya konan "davranış ve eylemler, konuşmalar, fiziki özellikler, diğer karakterlerin yorumu ve anlatıcın yorumu” şeklinde beş basamaktan oluşan sınıflama kullanılmıştır.

Araştırmada incelemeye konu olan masal türü eserlerde yer alan tüm karakterler, içerik analiziyle incelenmiştir. Araştırma verilerini desteklemesi bakımından betimsel analiz yöntemi de araştırmada kullanılmıştır. Araştırma sonucunda elde edilen veriler, yüzde ve sıklık (frekans) olarak ifade edilerek tablolaştırılmıştır.

\section{Geçerlik ve güvenirlik}

Araştırmanın güvenirliği açısından, araştırmada incelenen masal kitaplarından beş tanesi seçkisiz (random) örneklem olarak iki farklı araştırmacı tarafından birbirinden bağımsız olarak incelenmiştir. İki araştırmacının da birbirinden ayrı olarak gerçekleştirdiği değerlendirmeler arasındaki tutarlılığa bakılmıştır. Bu tespit için "Güvenirlik= Uzlaşma sayısı/ Uzlaşma+ Uzlaşmama sayısı" formülü (Tavşancıl ve Aslan, 2001) kullanılmıştır. Buna göre her iki bağımsız değerlendirme arasındaki tutarlılığın o,83 olduğu tespit edilmiştir. Bu sonuç, Akal'ın incelemeye konu masal kitaplarına yönelik metin çözümlemelerinin 0,70’in üstünde bir değer ifade etmesinden dolayı (Strauss ve Corbin, 1990) güvenilir olduğunu göstermektedir.

RumeliDE Dil ve Edebiyat Arastrmalar Dergisi Osmanağa Mahallesi, Mürver Ciçeği Sokak, No:14/8 Kadıköy - İSTANBUL / TÜRKIYE 34714 e-posta: editor@rumelide.com tel: +90 505 7958124, +90 2167730616
Address

RumeliDE Journal of Language and Literature Studies

Osmanağa Mahallesi, Mürver Çiçeği Sokak, No:14/8

Kadıköy - ISTANBUL / TURKEY 34714

e-mail: editor@rumelide.com,

phone: +90 505 7958124, +90 2167730616 


\section{Bulgular ve yorumlar}

Bu bölümde Aytül Akal'ın araştırma kapsamında belirlenen Güzel Dünyamıza Masallar, Çocuğuma Masallar ve Orman Masalları serilerine ait masal kitaplarındaki karakter çeşitleri ve karakter geliştirme yolları incelenerek tablolar halinde sunulmuştur. İncelemenin anlaşlabilirliği açısından bulgulara ilişkin yorumların ardından incelenen metinlerden doğrudan alıntılara yer verilmiştir.

Tablo 2. Güzel Dünyamıza Masallar serisindeki karakter çeşitleri

\begin{tabular}{lllllllll}
\hline \multirow{2}{*}{ Hikâyenin Adı } & \multicolumn{2}{l}{$\begin{array}{l}\text { Açık } \\
\text { karakter }\end{array}$} & \multicolumn{2}{l}{$\begin{array}{l}\text { Kapalı } \\
\text { karakter }\end{array}$} & \multicolumn{2}{c}{$\begin{array}{l}\text { Devingen } \\
\text { karakter }\end{array}$} & \multicolumn{2}{c}{$\begin{array}{l}\text { Durağan } \\
\text { karakter }\end{array}$} \\
\cline { 2 - 11 } & $f$ & $\%$ & $f$ & $\%$ & $f$ & $\%$ & $f$ & $\%$ \\
\hline Canı Sıkılan Aydede & 1 & 9,1 & 7 & 14,3 & 1 & 4,8 & 7 & 17,9 \\
\hline Cadı Burunlu Fabrika & 2 & 18,2 & 5 & 10,2 & 2 & 9,5 & 5 & 12,8 \\
\hline Park Yiyen Robot & 1 & 9,1 & 3 & 6,1 & 2 & 9,5 & 2 & 5,1 \\
\hline Denizin Altını Merak Eden Vapur & 1 & 9,1 & 5 & 10,2 & 1 & 4,8 & 5 & 12,8 \\
\hline Buruşuk Kâğıt Parçası & 1 & 9,1 & 8 & 16,3 & 1 & 4,8 & 8 & 20,5 \\
\hline Rengini Arayan Top & 1 & 9,1 & 4 & 8,2 & 2 & 9,5 & 3 & 7,7 \\
\hline Yaramaz Trafik Lambası & 1 & 9,1 & 5 & 10,2 & 1 & 4,8 & 5 & 12,8 \\
\hline Işı̆̆ını Yitiren Yıldız & 1 & 9,1 & 4 & 8,2 & 2 & 9,5 & 3 & 7,7 \\
\hline Bu Dünya Kimin & 2 & 18,2 & 8 & 16,3 & 9 & 42,9 & 1 & 2,6 \\
\hline Toplam & 11 & 18,3 & 49 & 81,6 & 21 & 35 & 39 & 65 \\
\hline
\end{tabular}

Güzel Dünyamıza Masallar serisinde toplam 6o karakter tespit edilmiştir. Tespit edilen karakterlerin \%81,6'sı kapalı karakter, \% 18,3'ü ise açık karakterlerden oluşmaktadır. En fazla açık karakter barındıran kitap Cadı Burunlu Fabrika $(\% 18,2)$ ve Bu Dünya Kimin $(\% 18,2)$; en fazla kapalı karaktere sahip olan kitaplar Buruşuk Kâğıt Parçası $(\% 16,3)$ ve Bu Dünya Kimin $(\% 16,3)$ 'dir. Bu seride belirlenen karakterlerin \%65\% durağan karakter, \%35\% ise devingen karakterlerden meydana gelmektedir. En fazla devingen karaktere sahip olan kitap Bu Dünya Kimin (\%42,9); en fazla durağan karaktere sahip olan kitaplarsa Buruşuk Kâğıt Parçası (\%20,5) ve Canı Sıkılan Aydede (\%17,9)'dir. Araştırma sonucunda genel itibarıyla masallardaki açı ve devingen karakterlerin başkişilerden, kapalı ve durağan karakterlerinse yardımcı karakterlerden meydana geldiği görülmüştür.

Tablo 3. Güzel Dünyamıza Masallar serisindeki karakter geliştirme yolları

\section{Karakter Geliştirme Yolları}

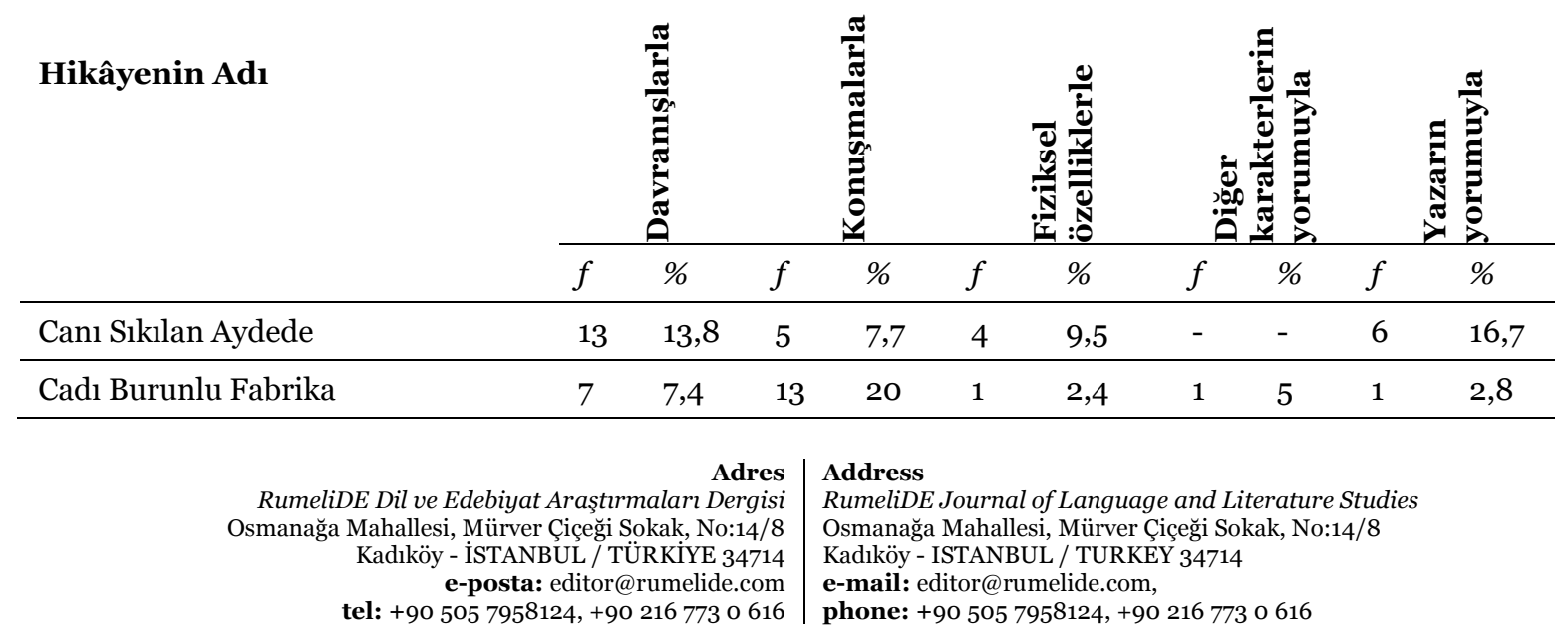




\begin{tabular}{lllllllllll}
\hline Park Yiyen Robot & 10 & 10,6 & 6 & 9,2 & 6 & 14,3 & 3 & 15 & 4 & 11,1 \\
\hline Denizin Altını Merak Eden Vapur & 15 & 16 & 7 & 10,8 & 8 & 19 & - & - & 2 & 5,6 \\
\hline Buruşuk Kâğıt Parçası & 12 & 12,8 & 7 & 10,8 & 7 & 16,7 & 3 & 15 & 9 & 25 \\
\hline Rengini Arayan Top & 4 & 4,3 & 8 & 12,3 & 8 & 19 & 2 & 10 & 5 & 13,9 \\
\hline Yaramaz Trafik Lambası & 16 & 17 & 3 & 4,6 & 4 & 9,5 & 2 & 10 & 4 & 11,1 \\
\hline Işı̆̆ını Yitiren Yıldız & 10 & 10,6 & 6 & 9,2 & 3 & 7,1 & 2 & 10 & 2 & 5,6 \\
\hline Bu Dünya Kimin & 7 & 7,4 & 10 & 15,4 & 1 & 2,4 & 7 & 35 & 3 & 8,3 \\
\hline Toplam & 94 & 36,6 & 65 & 25,3 & 42 & 16,3 & 20 & 7,8 & 36 & 14 \\
\hline
\end{tabular}

Tablo 3'e göre Güzel Dünyamıza Masallar serisinde en çok tercih edilen karakter geliştirme yolu, davranışlarla $(\% 36,6)$ 'dır. Bunu sırasıyla konuşmalarla (\%25,3), fiziksel özelliklerle $(\% 16,3)$, yazarın yorumuyla (\%14) ve diğer karakterlerin yorumuyla $(\% 7,8)$ izlemektedir. Davranışlarla karakter geliştirme açısından Yaramaz Trafik Lambası (\%17) ve Denizin Altın Merak Eden Vapur (\%16); konuşmalarla karakter geliştirme açısından Cadı Burunlu Fabrika (\%20) ve Bu Dünya Kimin (\%15,4); fiziksel özelliklerle karakter geliştirme açısından Denizin Altın Merak Eden Vapur (\%19) ve Rengini Arayan Top (\%19); yazarın yorumuyla karakter geliştirme açısından Buruşuk Kâğıt Parçası (\%25); diğer karakterlerin yorumuyla karakter geliştirme açısından Bu Dünya Kimin (\%7) adlı masal kitapları öne çıkmaktadır. Aşağıda karakter geliştirme yollarına dair tespit edilen bulguları desteklemesi açısından Güzel Dünyamıza Masallar serisindeki kitaplardan alıntılara yer verilmiştir:

"Çocuk üşenmemiş, hemen aynı gün belediyeye gidip sokak lambasının kırıldığını haber vermiş. Lambanın bulunduğu yeri de iyice tarif etmiş." (Davranışlarla karakter geliştirme, Işığını Yitiren Yıldız, s.13)

"Aman, sakın fabrikaları kapatmasınlar. Sonra annelerimiz ve babalarımız işsiz kalır. Hem fabrikalarda üretilen şeyler de insanlar için çok gereklidir.” (Konuşmalarla karakter geliştirme, Cadı Burunlu Fabrika, s.8)

"Sonra hepsi robotun bir parçasını söküp yerine bir dal, bir yaprak, bir çiçek takmışlar. O zaman park yiyen robot, tenekeden paslı bir robota değil, yeşil yapraklı bir ağaca benzemiş.” (Fiziksel özelliklerle karakter geliştirme, Park Yiyen Robot, s. 15)

“... Çocuksun ama birçok büyükten dikkatlisin. Çevreni inceliyor, her değişikliği fark ediyorsun. Eğer herkes senin gibi olsaydı, her yer düzenli, her yer tertemiz olurdu." (Diğer karakterlerin yorumuyla karakter geliştirme, Işı̆̆ını Yitiren Yıldız, s.11)

"Şişman adam kâğıdı görmüş, kaşlarını da çatmış. Ama eğilip alamamış. Çünkü kocaman bir göbeği varmış. Belli ki çocukluğundan beri pek sağlıksız beslenmiş. Yeterli meyve ve sebze yememiş." (Yazarın yorumuyla karakter geliştirme, Buruşuk Kâğıt Parçası, s.7)

Tablo 4. Çocuğuma Masallar serisindeki karakter çeşitleri

\begin{tabular}{|c|c|c|c|c|c|c|c|c|}
\hline \multirow{2}{*}{ Hikâyenin Adı } & \multicolumn{2}{|c|}{$\begin{array}{l}\text { Açlk } \\
\text { karakter }\end{array}$} & \multicolumn{2}{|c|}{$\begin{array}{l}\text { Kapalı } \\
\text { karakter }\end{array}$} & \multicolumn{2}{|c|}{$\begin{array}{l}\text { Devingen } \\
\text { karakter }\end{array}$} & \multicolumn{2}{|c|}{$\begin{array}{l}\text { Durağan } \\
\text { karakter }\end{array}$} \\
\hline & $f$ & $\%$ & $f$ & $\%$ & $f$ & $\%$ & $f$ & $\%$ \\
\hline Ben Büyüğüm & 1 & 11,1 & 3 & 6 & 1 & 8,3 & 3 & 6,4 \\
\hline Dağınık Çocuk & 1 & 11,1 & 9 & 18 & 1 & 8,3 & 9 & 19,1 \\
\hline Küçük Anne & 1 & 11,1 & 9 & 18 & 2 & 16,7 & 8 & 17 \\
\hline Nerden Çıktı Bu Kardeş & 1 & 11,1 & 4 & 8 & 1 & 8,3 & 4 & 8,5 \\
\hline Yaşlı Çocuk & 1 & 11,1 & 2 & 4 & 1 & 8,3 & 2 & 4,3 \\
\hline Terlikleri Kim Giyecek & 1 & 11,1 & 10 & 20 & 1 & 8,3 & 10 & 21,3 \\
\hline Bütün Oyuncaklar Benim & 1 & 11,1 & 5 & 10 & 3 & 25 & 3 & 6,4 \\
\hline \multicolumn{3}{|c|}{$\begin{array}{r}\text { RumeliDE Dil ve Edebiyat Arasstrrmaları Dergisi } \\
\text { Osmanağa Mahallesi, Mürver Ciçeği Sokak, No:14/8 } \\
\text { Kadıköy - İSTANBUL / TÜRKIYY } 34714 \\
\text { e-posta: editor@rumelide.com } \\
\text { tel: +90 } 5057958124,+902167730616\end{array}$} & \multicolumn{6}{|c|}{$\begin{array}{l}\text { Address } \\
\text { RumeliDE Journal of Language and Literature Studies } \\
\text { Osmanağa Mahallesi, Mürver Çiçeği Sokak, No:14/8 } \\
\text { Kadıköy - ISTANBUL / TURKEY } 34714 \\
\text { e-mail: editor@ @rumelide.com, } \\
\text { phone: +90 505 7958124, +90 } 216773 \text { o } 616\end{array}$} \\
\hline
\end{tabular}




\begin{tabular}{lllllllll}
\hline Ben Ne Zaman Büyüyeceğim & 1 & 11,1 & 3 & 6 & 1 & 8,3 & 3 & 6,4 \\
\hline Ben Ne Olacağım & 1 & 11,1 & 5 & 10 & 1 & 8,3 & 5 & 10,6 \\
\hline Toplam & 9 & 15,2 & 50 & 84,7 & 12 & 20,3 & 47 & 79,6 \\
\hline
\end{tabular}

Çocuğuma Masallar serisinde toplam 59 karakter tespit edilmiştir. Tespit edilen karakterlerin \%84,7'si kapalı karakter, \% 15,2'si ise açı karakterlerden oluşmaktadır. Serideki tüm masal kitaplarında birer tane açı karakter tespit edilmiştir. En fazla kapalı karaktere yer veren kitaplar Terlikleri Kim Giyecek (\%20), Kü̧̈ük Anne (\%18) ve Dağınk Çocuk (\%18)'tur. Bu seride belirlenen karakterlerin \%79,6'sı durağan karakterlerden, \%20,3’ü ise devingen karakterlerden meydana gelmektedir. En fazla devingen karaktere sahip olan kitap Bütün Oyuncaklar Benim (\%25), en fazla durağan karaktere sahip olan kitaplarsa Terlikleri Kim Giyecek $(\% 21,3)$ ve Dağını Çocuk $(\% 19,1)$ 'tur. Çocuğuma Masallar serisinde genel itibarıyla açık ve devingen karakterlerin başkişilerden, kapalı ve durağan karakterlerinse yardımcı karakterlerden meydana geldiği görülmüştür.

Tablo 5. Çocuğuma Masallar serisindeki karakter geliştirme yolları

\section{Karakter Geliştirme Yolları}

\begin{tabular}{|c|c|c|c|c|c|c|c|c|c|c|}
\hline \multirow[t]{2}{*}{ Hikâyenin Adı } & \multicolumn{2}{|c|}{ فีّ } & \multicolumn{2}{|c|}{ 泀 } & \multicolumn{2}{|c|}{ 包 } & \multicolumn{2}{|c|}{ 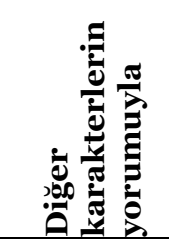 } & \multicolumn{2}{|c|}{ 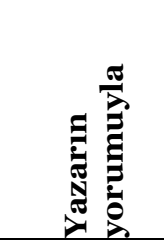 } \\
\hline & $f$ & $\%$ & $f$ & $\%$ & $f$ & $\%$ & $f$ & $\%$ & $f$ & $\%$ \\
\hline Ben Büyüğüm & 10 & 10,2 & 14 & 15,4 & 14 & 23,3 & 1 & 4 & 2 & 6,7 \\
\hline Dağınık Çocuk & 8 & 8,2 & 10 & 11 & 3 & 5 & 3 & 12 & 3 & 10 \\
\hline Küçük Anne & 21 & 21,4 & 20 & 22 & 31 & 51,7 & 4 & 16 & 3 & 10 \\
\hline Nerden Çıktı Bu Kardeş & 11 & 11,2 & 12 & 13,2 & 3 & 5 & 2 & 8 & 3 & 10 \\
\hline Yaşlı Çocuk & 4 & 4,1 & 12 & 13,2 & 1 & 1,7 & 4 & 16 & 2 & 6,7 \\
\hline Terlikleri Kim Giyecek & 12 & 12,2 & 10 & 11 & 4 & 6,7 & 2 & 8 & 4 & 13,3 \\
\hline Bütün Oyuncaklar Benim & 14 & 14,3 & 4 & 4,4 & 3 & 5 & - & - & 3 & 10 \\
\hline Ben Ne Zaman Büyüyeceğim & 9 & 9,2 & 2 & 2,2 & 1 & 1,7 & 3 & 12 & 9 & 30 \\
\hline Ben Ne Olacağım & 9 & 9,2 & 7 & 7,7 & - & - & 6 & 24 & 1 & 3,3 \\
\hline Toplam & 98 & 32,2 & 91 & 29,9 & 60 & 19,7 & 25 & 8,2 & 30 & 9,9 \\
\hline
\end{tabular}

Tablo 5'e göre Çocuğuma Masallar serisinde en çok tercih edilen karakter geliştirme yolu, davranışlarla $(\% 32,2)$ 'dır. Bunu sırasıyla konuşmalarla (\%29,9), fiziksel özelliklerle $(\% 19,7)$, yazarın yorumuyla $(\% 9,9)$ ve diğer karakterlerin yorumuyla $(\% 8,2)$ izlemektedir. Davranışlarla $(\% 21,4)$, konuşmalarla (\%22) ve fiziksel özelliklerle (\%51,7) karakter geliştirme açısından Küçük Anne; yazarın yorumuyla karakter geliştirme açısından Ben Ne Zaman Büyüyeceğim (\%30); diğer karakterlerin yorumuyla karakter geliştirme açısından Ben Ne Olacağım (\%24) adlı masal kitapları öne çıkmaktadır. Aşağıda karakter geliştirme yollarına dair tespit edilen bulguları desteklemesi açısından Çocuğuma Masallar serisindeki kitaplardan alıntılara yer verilmiştir:

\footnotetext{
Adres | Address

RumeliDE Dil ve Edebiyat Araşttrmalar Dergisi $\quad$ RumeliDE Journal of Language and Literature Studies Osmanağa Mahallesi, Mürver Çiçeği Sokak, No:14/8 Osmanağa Mahallesi, Mürver Çiçeği Sokak, No:14/8 Kadıköy - İSTANBUL / TÜRKIYE 34714 Kadıköy - ISTANBUL / TURKEY 34714 e-posta: editor@rumelide.com e-mail: editor@rumelide.com, tel: +90 505 7958124, +90 2167730616 phone: +90 505 7958124, +90 2167730616
} 
"Bütün oyuncakları isteyen çocuk sonunda oyuncakları almanın bir yolunu bulmuş. Hangi oyuncağı istiyorsa, arkadaşına göstermeden cebine koyuyor ya da ceketinin içine gizliyor ve evine götürüyormuş. Annesiyle gittiği yerlerden oyuncakla dönüp, onları odasında bir çekmecede biriktiriyormuş.” (Davranışlarla karakter geliştirme, Bütün Oyuncaklar Benim, s.5)

"Şuraya bakın! Yerlerde bıraktım diye ne hale gelmişler. Keşke onları yerlerine kaldırsaydım, ortalarda bırakmasaydım, demiş.” (Konuşmalarla karakter geliştirme, Dağınık Çocuk, s.15)

"Üç yaşında mini mini bir çocuk varmış. Küçücük elleri, küçücük ayakları, küçücük bir burnu varmış. Bu çocuğun bir de ağabeyi varmış. Ağabeyin elleri, ayakları, burnu kocamanmış.” (Fiziksel özelliklerle karakter geliştirme, Ben Büyüküm, s.3)

"Yaşlı ağaç devam etmiş: Terliyken soğuk su içmez, soğuk havalarda da iyi giyinirsen, hasta olmazsın. Ekran karşısında uzun süre oturmak da sağlı̆̆a zararlı, biliyor muydun? Neden bol bol spor yapmiyorsun? Ya sigara? Büyüyünce sigara içecek misin? -Asla, demiş çocuk.” (Diğer karakterlerin yorumuyla karakter geliştirme, Yaşlı Çocuk, s.13)

"Ama küçük kız, annesi görmeden buzağıyı eve nasıl sokacak? Küçük kız süt içmedi ki! Süt içmedi, büyümedi, güçlenmedi! Buzağıyı kucağında taşıyamaz.” (Yazarın yorumuyla karakter geliştirme, Küçük Anne, s.11)

Tablo 6. Orman Masalları serisindeki karakter çeşitleri

\begin{tabular}{|c|c|c|c|c|c|c|c|c|}
\hline \multirow{2}{*}{ Hikâyenin Adı } & \multicolumn{2}{|c|}{$\begin{array}{l}\text { Açık } \\
\text { karakter }\end{array}$} & \multicolumn{2}{|c|}{$\begin{array}{l}\text { Kapali } \\
\text { karakter }\end{array}$} & \multicolumn{2}{|c|}{$\begin{array}{l}\text { Devingen } \\
\text { karakter }\end{array}$} & \multicolumn{2}{|c|}{$\begin{array}{l}\text { Durağan } \\
\text { karakter }\end{array}$} \\
\hline & $f$ & $\%$ & $f$ & $\%$ & $f$ & $\%$ & $f$ & $\%$ \\
\hline Suda Oynamayı Kim Sevmez & 1 & 7,7 & 5 & 11,6 & 1 & 5,3 & 5 & 13,5 \\
\hline Küçük Kertenkele & 1 & 7,7 & 1 & 2,3 & 1 & 5,3 & 1 & 2,7 \\
\hline Ormandaki Apartman & 8 & 61,5 & 5 & 11,6 & 13 & 68,4 & - & - \\
\hline Masalını Arayan Ejderha & 1 & 7,7 & 23 & 53,5 & 2 & 10,5 & 22 & 59,5 \\
\hline Ormanın Renkleri Kimde & 1 & 7,7 & 5 & 11,6 & 1 & 5,3 & 5 & 13,5 \\
\hline Ormanın Yeni Komşuları & 1 & 7,7 & 4 & 9,3 & 1 & 5,3 & 4 & 10,8 \\
\hline Toplam & 13 & 23,2 & 43 & 76,7 & 19 & 33,9 & 37 & 66 \\
\hline
\end{tabular}

Orman Masalları serisinde toplam 56 karakter tespit edilmiştir. Tespit edilen karakterlerin \%76,7'si kapalı karakter, \% 23,2'si ise açık karakterlerden oluşmaktadır. En fazla kapalı karaktere yer veren kitap Masalın Arayan Ejderha (\%53,5); en fazla açık karaktere yer veren kitapsa Ormandaki Apartman (\%61,5)'dır. Bu seride belirlenen karakterlerin \%66'sı durağan karakterlerden, \%33,9'u ise devingen karakterlerden meydana gelmektedir. En fazla devingen karaktere sahip olan kitap Ormandaki Apartman $(\% 68,4)$, en fazla durağan karaktere sahip olan kitapsa Masalın Arayan Ejderha (\%59,5)'dır. Orman Masalları serisinde genel itibarıla açlk ve devingen karakterlerin başkişilerden, kapalı ve durağan karakterlerinse yardımcı karakterlerden meydana geldiği görülmüştür.

Address

RumeliDE Journal of Language and Literature Studies Osmanağa Mahallesi, Mürver Çiçeği Sokak, No:14/8

Kadıköy - ISTANBUL / TURKEY 34714

e-mail: editor@rumelide.com,

phone: +90 $5057958124,+902167730616$ 
Tablo 7. Orman Masalları serisindeki karakter geliştirme yolları

\section{Karakter geliştirme yolları}

\begin{tabular}{|c|c|c|c|c|c|c|c|c|c|c|}
\hline \multirow[t]{2}{*}{ Hikâyenin Adı } & \multicolumn{2}{|r|}{ : } & \multicolumn{2}{|c|}{ 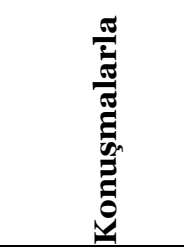 } & \multicolumn{2}{|c|}{ 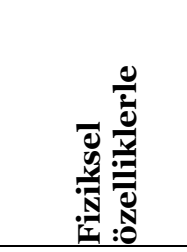 } & \multicolumn{2}{|c|}{ 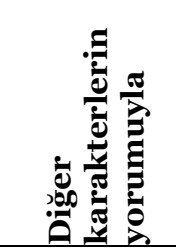 } & \multicolumn{2}{|c|}{ 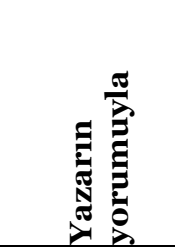 } \\
\hline & $f$ & $\%$ & $f$ & $\%$ & $f$ & $\%$ & $f$ & $\%$ & $f$ & $\%$ \\
\hline Suda Oynamayı Kim Sevmez & 14 & 20,9 & 7 & 16,7 & 15 & 53,6 & 2 & 20 & 1 & 8,3 \\
\hline Küçük Kertenkele & 9 & 13,4 & 6 & 14,3 & 4 & 14,3 & 3 & 30 & 1 & 8,3 \\
\hline Ormandaki Apartman & 12 & 17,9 & 5 & 11,9 & 4 & 14,3 & - & - & 3 & 25 \\
\hline Masalını Arayan Ejderha & 11 & 16,4 & 14 & 33,3 & 3 & 10,7 & - & - & 1 & 8,3 \\
\hline Ormanın Renkleri Kimde & 9 & 13,4 & 4 & 9,5 & - & - & 3 & 30 & 4 & 33,3 \\
\hline Ormanın Yeni Komşuları & 12 & 17,9 & 6 & 14,3 & 2 & 7,1 & 2 & 20 & 2 & 16,7 \\
\hline Toplam & 67 & 42,1 & 42 & 26,4 & 28 & 17,6 & 10 & 6,3 & 12 & 7,5 \\
\hline
\end{tabular}

Tablo 7’ye göre Orman Masalları serisinde en çok tercih edilen karakter geliştirme yolu, davranışlarla $(\% 42,1)$ 'dir. Bunu sırasıyla konuşmalarla $(\% 26,4)$, fiziksel özelliklerle $(\% 17,6)$, yazarın yorumuyla $(\% 7,5)$ ve diğer karakterlerin yorumuyla $(\% 6,3)$ izlemektedir. Davranışlarla karakter geliştirme açısından Suda Oynamayı Kim Sevmez (\%20,9), Ormandaki Apartman (\%17,9) ve Ormanı Yeni Komşuları (\%17,9); konuşmalarla karakter geliştirme açısından Masalın Arayan Ejderha (\%33,3); fiziksel özelliklerle karakter geliştirme açısından Suda Oynamayı Kim Sevmez (\%53,6); yazarın yorumuyla karakter geliştirme açısından Ormanın Renkleri Kimde (\%33,3), Ormandaki Apartman (\%25); diğer karakterlerin yorumuyla karakter geliştirme açısından Ormanın Renkleri Kimde (\%30) ve Küçük Kertenkele (\%30) adlı masal kitapları öne çıkmaktadır. Aşağıda karakter geliştirme yollarına dair tespit edilen bulguları desteklemesi açısından Orman Masalları serisindeki kitaplardan alıntılara yer verilmiştir:

"Kazı işini çok iyi bilen tavşanlar, köstebekler ve yılanlar da kazıya yardımcı olmuşlar. Tuğlaların taşınmasına maymunlar yardım etmiş, üst üste dizilip harçlanmasına zürafalar... Filler ise binanın boyanmasında gönüllü olarak çalışmış, boyayı hortumlarıyla püskürterek binanın çabucak bitmesi için ellerinden geleni yapmışlar." (Davranışlarla karakter geliştirme, Ormandaki Apartman, s.5)

“Ayı karşı çıkmış: Siz mışıl mışıl uyurken ben çalıştım, çiçek topladım. Tembellik etmek yerine siz de çalışın, kendinize bir iş bulun." (Konuşmalarla karakter geliştirme, Ormanın Renkleri Kimde, S.11)

"Canavara benzeyen kocaman bir kafası, keskin sivri dişleri ve uzuuun bir kuyruğu varmış." (Fiziksel özelliklerle karakter geliştirme, Küçük Kertenkele, s. 5)

"Hem annenizin sözünü dinlemiyor hem de arkasından gülüyorsunuz. Oysa anneniz yalnızca sizin iyiliğinizi düşünüyordu.” (Diğer karakterlerin yorumuyla karakter geliştirme, Suda Oynamayı Kim Sevmez, s.13)

"Ne mi olmuştu? Ayı, ormanın renklerini çalmıştı! Oysa çiçekler, ormanda yaşayan herkesin değil miydi?” (Yazarın yorumuyla karakter geliştirme, Ormanın Renkleri Kimde, s.15)

\footnotetext{
RumeliDE Dil ve Edebiyat Araștırmaları Dergisi Osmanağa Mahallesi, Mürver Ciçeği Sokak, No:14/8 Kadıköy - İSTANBUL / TÜRKIYE 34714 e-posta: editor@rumelide.com tel: +90 505 7958124, +90 2167730616

Address

RumeliDE Journal of Language and Literature Studies Osmanağa Mahallesi, Mürver Çiçeği Sokak, No:14/8

Kadıköy - ISTANBUL / TURKEY 34714

e-mail: editor@rumelide.com,

phone: +90 505 7958124, +90 2167730616
} 


\section{Sonuç ve tartışma}

Araştırmada karakter çeşitleri ve karakter geliştirme yolları açısından incelenmiş olan üç masal kitabı serisinin sonuçları da birbirleriyle benzerlik göstermektedir. Güzel Dünyamıza Masallar serisinde tespit edilen toplam 60 karakterin \%81,6'sı kapalı karakter, \% 18,3’ü ise açık karakter; Çocuğuma Masallar serisinde tespit edilen toplam 59 karakterin \%84,7'si kapalı karakter, \% 15,2'si açık karakter; Orman Masalları serisinde tespit edilen toplam 56 karakterin \%76,7'si kapalı karakter, \% 23,2'si ise açık karakterlerden oluşmaktadır. Bu sonuçlar, incelenen eserlerdeki kahramanların büyük bir kısmının kapalı karakterlerden oluşması bakımından Baş ve Ucuzsatar'ın (2020) okul öncesi çocuk kitaplarındaki hayvan karakterler üzerine yaptıkları araştırma sonuçlarıyla aynıdır. Buna göre açık karakter özelliği gösteren başkişileri desteklemesi, kurguda çatışma unsuru sağlaması veya ana karaktere yardımcı olarak anlatımı güçlü kılması bakımından kapalı karakterlere yer verilmelidir (Baş ve Ucuzsatar, 2020: 349). Nitekim çocuk kitaplarında çocuk okurlara verilecek mesajlar, daha ziyade açık karakterlerin söz, davranış vb. nitelikleri üzerinden olumlu model oluşturacak şekilde verilmektedir. Bulut (2018: 726), yazınsal karakterlerle ilgili yaptığı araştırmasında kitap seçiminde karakterlerin önemine işaret ederek seçilen karakterin çocukların okuma sürecinde kitapla etkileşimine, karakterlerle özdeşim kurmalarına imkân sunduğunu ifade etmektedir.

Güzel Dünyamıza Masallar serisinde tespit edilen karakterlerin \%65'i durağan karakter, \%35’i ise devingen karakter; Çocuğuma Masallar serisinde tespit edilen karakterlerin \%79,6'sı durağan karakter, \%20,3'ü ise devingen karakter; Orman Masalları serisinde tespit edilen karakterlerin \%66'sı durağan karakterlerden, \%33,9'u ise devingen karakterlerden meydana gelmektedir. Bu sonuç, Baş ve Ucuzsatar'ın (2020: 349) okul öncesi dönem çocuk kitaplarındaki hayvan karakterler üzerine yaptığı araştırma sonuçlarıyla aynıdır. Her üç seride de karakterlerin büyük bir kısmının durağan karakter özelliği göstermesinin sebebi, genel itibarıyla her üç masal serisinde de açık ve devingen karakterlerin başkişilerden, kapalı ve durağan karakterlerinse yardımcı karakterlerden meydana gelmiş olmasıdır. Eserlerde yer alan başkarakterlerin sayıca yardımcı karakterlerden az oluşu bu sonucun nasıl ortaya çıktığını açıklamaktadır. Çünkü metinlerdeki olayların gelişmesi ve sürükleyiciliği açısından başkişilerin önemi büyüktür. Sever'e göre (2015: 115) eserdeki kahramanların sayıca fazla olması, okurun hangi kahramanla özdeşim kuracağını şaşırması ve nihayetinde okuma eyleminden uzaklaşabilmesi riski taşımaktadır. Başkişilerin devingen olarak öne çıkması ve diğer karakterlerden ayrışması, özellikle küçük yaşlardaki çocukların sağlıklı özdeşim kurabilmelerine yardımcı olması bakımından olumlu görülebilir. Ancak hatalardan arınık olarak idealize edilmiş karakterlerin, çocuğun özdeşim kurması açısından birtakım sorunlara yol açacağı unutulmamalıdır. Özmen'e (2016: 23) göre çocuk kitaplarında kahramanların ve yaşamın tüm yönleriyle birlikte aktarılması, gerçek hayatın hem iyi hem de kötü tarafları olabileceği mesajını taşıdığı için gerçek yaşamda çocuğun yaşayabileceği hayal kırıklıklarını da önleyecektir. Bulut'a (2018: 727) göre öğretmenlerin, içinde hatalar yapabilen ama bunlara çözümler arayan, düzeltmek için çabalayan gerçek bir çocuk özellikleri gösteren karakterler bulunan kitaplara yönelmeleri gerekmektedir. Çünkü bu nitelikteki kitaplarda yer alan başkişi, daha ziyade birtakım tecrübeler sonrasında hatasını anlayan, davranış değiştiren devingen karakterler olarak öne çıkmaktadırlar. Sever'e (2015: 114-115) göre herhangi bir dirençle karşılaşmadan, olayla ilgili bir nedensellik ilişkisi kurulmadan gerçekleşen değişimler, kitaptaki karaktere karşı çocuğun güvensizlik hissetmesine sebep olabilir.

Araştırma sonucunda ulaşılan bir diğer bulgu ise tüm masal serilerinde ve incelenen hemen hemen tüm kitaplarda Lukens’in (2007) karakter geliştirme yollarının her birinin kullanılmasıdır. Bu sonuç, Baş ve Ucuzsatar'ın araştırma sonuçlarıyla aynıdır. Buna göre bir eserdeki karakterlerin farklı

Adres Address

RumeliDE Dil ve Edebiyat Araştırmalar Dergisi $\quad$ RumeliDE Journal of Language and Literature Studies Osmanağa Mahallesi, Mürver Çiçeği Sokak, No:14/8 Osmană̆a Mahallesi, Mürver Çiçeği Sokak, No:14/8 Kadıköy - İSTANBUL / TÜRKIYE 34714 Kadıköy - ISTANBUL / TURKEY 34714 e-posta: editor@rumelide.com e-mail: editor@rumelide.com, tel: +90 505 7958124, +90 2167730616 phone: +90 505 7958124, +90 2167730616 
şekillerle geliştirilmesi, okura karakterin niteliklerini anlamlandırması açısından kolaylık sağlamakla birlikte, çocukların karakterleri tek boyutlu değil, pek çok farklı özelliğiyle tanımasına da olanak tanımaktadır (Baş ve Ucuzsatar, 2020: 349).

İncelenen tüm masal serilerinde davranışlarla karakter geliştirme, en çok tercih edilen karakter geliştirme yolu olarak öne çımıştır. Bu sonuç, Önder'in (2019) Gülçin Alpöge'nin eserlerinde kullandığı karakter geliştirme yolları üzerine yaptığı çalışmasının sonuçlarıyla aynıdır. Önder, araştırmasında Alpöge'nin eserlerinde en çok kullandığ 1 karakter geliştirme yolunun karakterlerin davranış ve eylemleriyle olduğu sonucuna ulaşmıştır (Önder, 2019: 133). Ural'a (2013: 48) göre, çocuklar okuduğu kitaplardaki karakterlerin karşılaştığı sorunları görünce sadece kendisinin sorunları olmadığını görerek rahatlar ve özgüveni gelişir. Bununla birlikte karakterlerin davranışları çocuğa sosyal ve etik değerler de kazandırmaktadır. Nitekim Ceran'a (2015: 153) göre yazar, bir çocuğa vermek istediği mesaj ve çocukta meydana getirmek istediği kişilik özelliğini ana kahramana yüklemektedir.

En çok başvurulan karakter geliştirme yollarından ikincisiyse konuşmalar yoluyladır. Eser kahramanlarının olaylar karşısındaki tavırları, diğer karakterlerle ilişkileri, eser sonunda devingen karakter özellikleri bağlamındaki olumlu dönüşümleri kadar söyledikleri de çocuk okurlar açısından kahramanların model olarak benimsenmesine neden olmaktadır. Türkçe ders kitaplarındaki öykü metinlerinde yer alan karakter geliştirme yolları üzerine yaptığı araştırmasında en çok başvurulan karakter geliştirme yolunun konuşmalar vasitasiyla olduğunu tespit eden Karagül'e (2019: 300) göre çocuğa, konuşarak kendini ifade edebilmeyi ve kendini başkalarına tanıtmayı yazınsal kurgu yoluyla sezdirmesi açısından bu bulgu oldukça önemlidir.

Fiziksel özelliklerle karakter geliştirme, Akal'ın kitaplarında rastlanan bir diğer bulgudur. Karakterlerin fiziki niteliklerinin öne çıkarılarak sunulması, anlatılanların çocuğun zihninde şekillenmesi, somutlaşması bakımından değerlidir. Ancak bu noktada unutulmamalıdır ki özellikle okul öncesi dönem çocuk kitaplarında fiziksel özelliklerle karakter geliştirme, resimler üzerinden gerçekleştirilmektedir (Baş ve Ucuzsatar, 2020: 350).

İncelemeye konu masal serilerinde yazarın yorumuyla karakter geliştirmeye de yer verildiği görülmektedir. Çocuk okurun eserde verilmek istenen mesajı doğru algılaması, istendik düzeydeki değer, tutum ve davranışların kazandırılması için çocuğun sağlıklı şekilde yönlendirilmesi bakımından yazarın eser içerisindeki yorumları değerlidir. Ancak bu noktada Eziler Kıran ve Kıran'ın, çocuğun kitaptaki karakteri önyargısız şekilde tanıyarak nesnel görüşlere sahip olması, yazarın bıraktığı anlamsal boşlukları kendi âleminde doldurması için başkalarının yorumlarını içeren bilgiler olmaksızın tanıma firsatı yakalaması gerektiğini yönündeki görüşleri de göz önünde bulundurulmalıdır (2003: 153).

Tüm seriler içerisinde en az tercih edilen, diğer karakterlerin yorumlarıyla karakter geliştirmedir. Baş ve Ucuzsatar'ı araştırma sonuçları, bu bulguyu destekler niteliktedir. Eserde yer alan karakterlerin tavır, davranış, söz ve tutumlarının diğer karakterler tarafından onaylanması veya reddedilmesi, ana karakterle özdeşim kuran çocuğun kahramanı çok yönlü tanıması, kişiliği hakkında fikir edinmesi için önem taşımaktadır (Baş ve Ucuzsatar, 2020: 350).

Çocuk edebiyatı yapıtlarında tek bir yolla karakter betimleme, karakterin derinlikten uzak olmasına, hikâye sonucununsa kalıplaşmış yargı olmasına sebep olabileceği için (Karatay, 2016: 103) dikkat

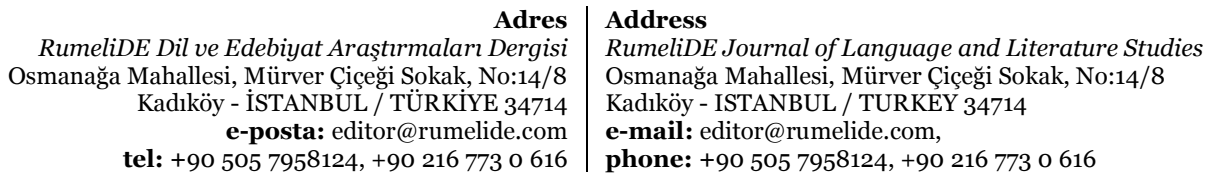


edilmesi gereken bir husustur. Araştırma sonucunda Aytül Akal'ın araştırmaya konu çocuk masalları serilerinde, kimi daha çok kimi daha az olmak üzere, Lukens’in belirlediği karakter geliştirme yollarının hepsinin kullanıldığı tespit edilmiştir.

\section{Kaynakça}

Baş, B. ve Ucuzsatar, N. (2020). Okul Öncesi Çocuk Kitaplarındaki Hayvan Karakterlerin Geliştirilme Yolları Açısından İncelenmesi, Uluslararası Türkçe Edebiyat Kültür Eğitim Dergisi, 9(1), 336353 .

Bettelheim, B. (2019). Masallarm Büyüsü, İstanbul: İnkılâp Yayıncılık.

Bulut, S. (2018). Okulöncesi Dönem Öğretmenlerinin Çocuk Edebiyatı Yapıtlarını Seçme Ölçütü Olarak Yazınsal Karakterlere Yükledikleri Anlam. Ana Dili Eğitimi Dergisi, 6(3), 714-729.

Burç, B. (2013), Rıfat Ilgaz’n Bacaksızın Başından Geçenler Adlı Hikâye Serisindeki Eserlerin Çocuğa Görelik İlkesi Açısından İncelenmesi, (Yayımlanmamış yüksek lisans tezi), Fırat Üniversitesi/ Eğitim Bilimler Enstitüsü, Elazı̆̆.

Ceran, D. (2015). Çocuklara Rol Model Olması Bakımından Millî Mücadele Kahramanları ve Edebî Eserlere Yansıması: "Kurtuluşun Kahramanları" Kitap Dizisi Örneği, Journal of History School, 8(XXIV), 135-157.

Dilidüzgün, S. (2005). Türkiye'de Çocuk Edebiyatına Bakışlar ve Çağdaş Çocuk Edebiyatı, Çocuk ve İlkgençlik Edebiyatı Kurultayı. İstanbul: Maltepe Üniversitesi No:25, 37-46.

Dursunoğlu, H. (2013). Eğitim Fakülteleri İçin Çocuk Edebiyatı (4.Baskı). Ö. Yılar ve L. Turan (ed.), Çocuk-Edebiyat ve Çocuk Edebiyatı içinde (s.1- 36). Ankara: Pegem Akademi.

Erdoğan, F. (2019). Çocuklar İçin Yazmak, İstanbul: Binbirkitap.

Eziler Kıran A. \& Kıran Z. (2003). Yazınsal Okuma Süreçleri. Ankara: Seçkin.

Karagül, S. (2019). Ortaokul Türkçe Ders Kitaplarında Yer Alan Öykü Metinlerindeki Karakter Geliştirme Yollarının İncelenmesi, Başkent University Journal of Education, 6(2), 293-303.

Karasar, N. (2009). Bilimsel Araştırma Yöntemi. Ankara: Nobel.

Karataş, E. (2014) Çocuk Edebiyatında "Karakter” Kavramı, Muğla Sıtkı Koçman Üniversitesi Sosyal Bilimler Enstitüsü Dergisi, Sayı 33, 60-79.

Karatay, H. (2016). Çocuk Edebiyatı Metinlerinde Bulunması Gereken Özellikler. Tacettin Şimşek (Ed.), Kuramdan Uygulamaya Çocuk Edebiyatı içinde (s. 81-129). Ankara: Grafiker.

Kıymaz, M. S. (2019). Türk Çocuk ve Gençlik Edebiyatında Roman: Dönemeç Romanında Kahramanların Yaşadığı Dönüşümler. Turkish Studies, 14(2), 625-642.

Lukens, R. J. (2007). A Critical Handbook of Children's Literature. 8 th ed. USA: Allyn \& Bacon, Incorporated.

Oğuzkan, F. (2000). Çocuk Edebiyatı. Ankara: Anı.

Özmen, S. (2016). Çocuk Hikâyelerindeki Kahramanlarm Çocuklara Rol-Model Olma Durumları, (Yayımlanmamış yüksek lisans tezi), Fırat Üniversitesi/ Eğitim Bilimleri Enstitüsü, Elazı̆̆.

Rundell, K. (2020). Neden Çocuk Kitapları Okumalıyız. (Çev. Şiirsel Taş), İstanbul: Domingo.

Seven, S., (2010). Edebi Metinlerle Çocuk Edebiyatı. Şener Demirel (Ed.), Ankara: Pegem Akademi.

Sever, S. (2015). Çocuk ve Edebiyat. Ankara: Tudem.

Strauss, A. \& J. Corbin (1990). Basics of Qualitative Research: Grounded Theory Procedures and Techniques. Newbury Park: Sage Publications.

Şimşek, T. (2011). Kuramdan Uygulamaya Çocuk Edebiyatı El Kitabı. Ankara: Grafiker Yayınları.

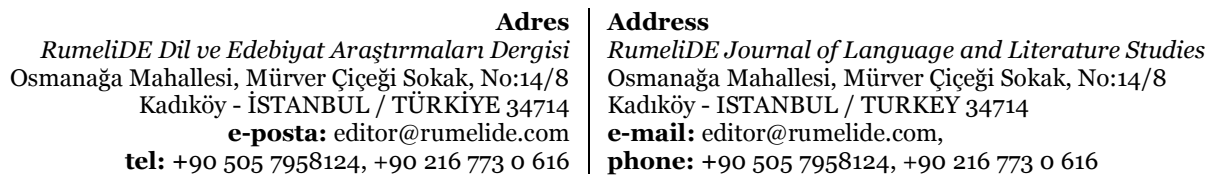


Şirin, R.M. (1998). Çocuk Edebiyatı Ders Notları. https://docplayer.biz.tr/2530959-Cocuk-edebiyatiders-notlari-mustafa-ruhi-sirin.html

Tavşancıl, E. ve A. E. Aslan (2001). Sözel, Yazıl ve Diğer Materyaller İçin İçerik Analizi ve Uygulama Örnekleri. İstanbul: Epsilon.

Ural, S. (2013). Çocuk Edebiyatı. Mübeccel Gönen (Ed.), Ankara: Eğiten Kitap. 